The Nature and Application of Biocontrol Microbes II: Trichoderma spp.

\title{
Understanding the Mechanisms Employed by Trichoderma virens to Effect Biological Control of Cotton Diseases
}

\author{
Charles R. Howell
}

Research Plant Pathologist, U.S. Department of Agriculture-Agricultural Research Service, CPRU, College Station, TX 77845. Accepted for publication 29 May 2005.

After 25 years of working with bacteria, actinomycetes, and fungi as biocontrol agents of cotton seedling and root diseases, I believe Trichoderma virens to be one of the most versatile and effective biocontrol agents we have studied. The species contains an arsenal of mechanisms and antimicrobial metabolites that give it a wide spectrum of activity against different pathogens $(1,6,7$, $22,29,30)$, and the capacity to control a number of diseases $(4,6$, $7,9,20,29,30)$.

To a biocontrol scientist, one of the salient features of Trichoderma virens, and one of the reasons it has been so frequently studied, is that it is an aggressive mycoparasite of other fungi $(7,22,23)$, many of which are plant pathogens. It not only parasitizes the hyphae of many fungal species, but it also can penetrate and destroy some of the resting structures, thereby reducing their inoculum potential in soil $(1,7,22)$. Mycoparasitism in T. virens has been associated with its capacity to synthesize extracellular chitinase (2). In addition to its mycoparasitic character, T. virens is also a vigorous saprophyte that can be cultured on any one of a number of substrates and can maintain itself in the absence of the host.

Concomitant with its mycoparasitic activities, T. virens also produces several potent epithiodiketopiperazine antibiotics. The antibiotic gliotoxin, (24) which is produced by "Q" strains of $T$. virens, has a wide spectrum of activity against bacteria, actinomycetes, and fungi. Gliotoxin has also been reported to act synergistically with chitinase in the antifungal activities of T. virens (3). The antibiotic gliovirin (16) produced by "P" strains of this fungus, although closely related to gliotoxin, has a much more restricted spectrum of activity, and it is not effective against bacteria, actinomycetes, or most fungi. It is, however, a potent inhibitor of oomycetes, such as Pythium and Phytophthora species. "Q" strains of $T$. virens do not produce gliovirin, and "P" strains do not produce gliotoxin (19). When either "P" or "Q" strains of $T$. virens are grown on substrates with high $\mathrm{C} / \mathrm{N}$ ratios, they both produce the steroid-like compound viridiol. Viridiol has little or no antibiotic activity, but it is a potent phytotoxin when placed in contact with the roots of plants. With proper placement, i.e., mixed into surface soil, it can act as an effective herbicide for

Corresponding author: C. R. Howell; E-mail address: chowell@cpru.usda.gov

DOI: 10.1094/PHYTO-96-0178

This article is in the public domain and not copyrightable. It may be freely reprinted with customary crediting of the source. The American Phytopathological Society, 2006 weeds, without harm to the crop plant that is planted at greater depth (17). It has recently been discovered that strains of $T$. virens produce a mixture of peptaibols, linear peptide antibiotics, but their role in biological control is as yet unknown (25).

With antimicrobial mechanisms such as mycoparasitism and antibiotic production present, it would stand to reason that they play an important role in the biocontrol activities of this fungus. It was this hypothesis that guided most of our early research $(1,7$, 16,15,22-24,26). This, however, does not appear to be the case for cotton seedling diseases. When mutants of $T$. virens deficient for mycoparasitism, antibiotic production, or both were induced with UV light, they proved to be as biocontrol effective as the parent strains $(8,18)$. In addition, $T$. virens strains grown on substrates that do not induce antibiotic production are just as effective as biocontrol agents of cotton seedling disease as those that are grown on substrates that do induce antibiotic production.

If the mechanisms of mycoparasitism and antibiosis are not vital to biological control by $T$. virens, what mechanisms are? By culturing fungi from the roots of treated cotton plants taken at intervals from field plantings throughout the growing season, we discovered that $T$. virens could be recovered from surface-sterilized roots at any time. The fungus colonized the tap and secondary roots in the upper reaches of the soil. However, late in the season it was found mostly on the tap and primary roots (28). Because the roots were rigorously surface-sterilized, we surmised that the fungus had penetrated the roots. This hypothesis was later supported by colleagues in Israel working with T. harzianum. They demonstrated microscopically that the fungus penetrated the epidermis and grew into the outer layers of the root cortex where it induced defense responses in cucumber (27).

We discovered that colonization of the cotton root by $T$. virens induced the synthesis of high levels of the terpenoid aldehydes hemigossypol (HG) and desoxyhemigossypol (dHG) that are intermediates in the pathway leading to synthesis of the dimer, gossypol. Bioassay of these compounds and gossypol against Rhizoctonia solani showed that both intermediates were strongly inhibitory to the pathogen, with $\mathrm{dHG}$ showing twice the toxicity of HG. Gossypol was only slightly inhibitory to $R$. solani. Bioassay of $\mathrm{HG}$ against $T$. virens and $T$. koningii showed that both fungi were resistant to the toxin (14). It was later learned that $T$. virens induced terpenoid synthesis in the cotton root by production of an 18-kDa protein that elicited both increased peroxidase activity and terpenoid concentrations in inoculated roots (5). Research has shown that there is a strong correlation between the 
ability of a strain of $T$. virens to induce terpenoid synthesis in cotton roots and its efficacy as a biocontrol agent of cotton seedling disease (14). Strains that do not induce terpenoid synthesis do not protect the root from subsequent infection by a pathogen. However, protection of the root by $T$. virens does not extend to the hypocotyl. No increase in peroxidase activity or terpenoid synthesis could be detected in the above-ground parts of $T$. virenstreated cotton plants (14).

Apparently, induction of phytoalexin synthesis in the roots of the cotton plant also protects it from the vascular wilt pathogens that enter through the root. Seed treatment of cotton with T. virens, and subsequent colonization of the developing root system, suppressed symptom development of Verticillium and Fusarium wilts of cotton when the plants were subsequently inoculated with the pathogens $(4,30)$.

Another mechanism that $T$. virens employs in the biological control of the preemergence phase of cotton seedling disease that is incited by Pythium ultimum, Pythium aphanidermatum, or Rhizopus oryzae has recently been discovered. During the germination process, disease-susceptible cotton seeds release to the spermosphere compounds that stimulate resting structures of the pathogens in the surrounding soil to germinate and infect the seed. Seeds of resistant cultivars do not release these compounds. Seed treatment of susceptible cultivars with preparations of $T$. virens prevents infection of the seed by disrupting the process. The biocontrol agent coated onto the seed metabolizes the germination stimulatory compounds before they reach the pathogen propagules in the soil (10). Dead cells of $T$. virens are ineffective as biocontrol agents (11). The enzymes responsible for metabolism of the compounds that stimulate pathogen propagule germination are contained within the hyphal cells of T. virens. Exposure of the stimulatory compounds to cultures of $T$. virens destroys their stimulatory activity, while exposure to cell-free filtrates of $T$. virens cultures does not result in a loss of activity when the compounds are recovered and bioassayed (unpublished data).

The failure of cotton seed treatments with $T$. virens to induce phytoalexin synthesis in the above-ground parts of the plant leaves the hypocotyls unprotected and subject to postemergence damping-off by Rhizoctonia solani. Postemergence damping-off of cotton incited by $R$. solani can be controlled by application of the systemic fungicide Chloroneb 65W (1,4-dichloro-2,5-dimethoxybenezene) (21). However, this fungicide is not effective in the control of all preemergence pathogens. In soils where only pre- or postemergence pathogens occur, the biocontrol agent or the fungicide, respectively, can give effective control. In soils where both kinds of pathogens occur simultaneously, the most effective solution would appear to be a combination seed treatment containing both the fungicide and the biocontrol agent. However, Chloroneb is just as toxic in vitro to $T$. virens as it is to $R$. solani, leaving in question whether or not such a combination seed treatment is feasible. To test the efficacy of combination seed treatments in disease control, the seeds of a disease-susceptible cotton cultivar were first treated with one half the standard concentration of Chloroneb and air-dried. This was followed by coating the seed with latex sticker, and dusting the seed with a dry granular preparation of $T$. virens. These combination-treated seeds, along with untreated, Chloroneb-treated, or T. virens-treated controls, were planted in soil naturally infested with preemergence damping-off pathogens and amended with $R$. solani. After 7 days incubation at $25^{\circ} \mathrm{C}$, seedlings from untreated, Chloroneb-treated, or T. virenstreated seeds did not emerge. Seedlings from combination-treated seeds emerged and remained healthy during subsequent development (12). Apparently, the systemic fungicide Chloroneb is absorbed by the seedling, protecting it from infection by $R$. solani. The latex polymer shields the $T$. virens in the biocontrol preparation from the effects of the fungicide.

When seeds of a highly susceptible cotton cultivar are treated with a "Q" strain preparation of $T$. virens and planted in soil infested with preemergence damping-off pathogens, seedlings emerge normally and appear to be healthy. When seeds of the same cultivar are treated with preparations of "P" strains of $T$. virens and planted in infested soil, no emergence is observed. This difference between " $\mathrm{P}$ " and "Q" strains is not apparent with disease-resistant cultivars. The initial impression with susceptible cultivars is that the "P" strains are not capable of controlling the disease. However, when "P" strain-treated seeds are planted in noninfested soil, or in sterile vermiculite, they still do not emerge. This indicates that "P" strains of $T$. virens are pathogenic to susceptible cotton cultivars, while "Q" strains are not. Why is this so? A comparison of the enzymatic activities and viridiol (herbicide) production by "P" and "Q" strains indicates that there is little or no difference between the two, and seed treatment with the antibiotic gliovirin appears to have no effect on seed germination and seedling development. The answer to the puzzle appears to lie in the fact that "Q" strains induce high levels of phytoalexin production in cotton roots, while " $\mathrm{P}$ " strains do not. Taken together, these results indicate that both "P" and "Q" strains of T. virens are potential pathogens, but that cotton roots are able to contain further invasion by "Q" strains through production of induced phytoalexins. "P" strains do not induce sufficient phytoalexin production by cotton roots, and they are therefore much less restrained in their invasion and destruction of host plant tissue (15).

The ability of $T$. virens to act as a mycoparasite, synthesize antibiotic compounds, and to grow saprophytically at an impressive rate make it an effective competitor in the soil and root environment. On those pathogens whose resting structures are susceptible to infection by $T$. virens, the mycoparasite can be used to reduce pathogen inoculum potential in the soil. Other characteristics of $T$. virens make it an effective biocontrol agent of plant diseases when it is cultured, stored, and applied properly as a seed or soil treatment. The ability of "Q" strains to colonize and penetrate the epidermis and cortex of plant root systems, and to synthesize elicitor proteins, can lead to the induction of increased peroxidase activity and phytoalexin synthesis in the roots. These phenomena protect the developing plant root system from subsequent infection by root rotting and vascular wilt pathogens. The ability of $T$. virens strains to metabolize the pathogen propagule stimulatory compounds that are emitted by germinating cotton seedlings before they reach pathogen resting propagules is also an effective means of controlling preemergence seedling disease. It allows the seed to escape infection because the pathogen is not stimulated by the plant. If pathogen propagules are artificially stimulated to germinate, seed treatment with $T$. virens does not afford the plant any protection from early seedling disease. Lastly, the ability of $T$. virens to function as a biocontrol seed treatment in the presence of systemic fungicides coated on the seed $(12,13)$ has greatly expanded the activity spectrum of the fungus as a biocontrol agent. Taken together, the characteristics exhibited by strains of $T$. virens make it one of the most effective and versatile biocontrol agents for seedling and root disease. The next steps in improving the biocontrol efficacy of $T$. virens strains are to expand their temperature/activity spectra and extend the storage period during which the biocontrol preparations remain effective.

\section{LITERATURE CITED}

1. Aluko, M. O., and Herring, T. F. 1970. The mechanisms associated with the antagonistic relationship between Corticium solani and Gliocladium virens. Trans. Br. Mycol. Soc. 55:173-179.

2. Baek, J. M., Howell, C. R., and Kenerley, C. M. 1999. The role of extracellular chitinase from Trichoderma virens Gv29-8 in the biocontrol of Rhizoctonia solani. Curr. Genet. 35:41-50.

3. Di Pietro, A., Lorito, M., Hayes, C. K., Broadway, R. M., and Harman, G. E. 1993. Endochitinase from Gliocladium virens: Isolation, characterization and synergistic antifungal activity in combination with gliotoxin. Phytopathology 83:308-313. 
4. Hanson, L. E. 2000. Reduction of Verticillium wilt symptoms in cotton following seed treatment with Trichoderma virens. J. Cotton Sci. 4:224-231.

5. Hanson, L. E., and Howell, C. R. 2004. Elicitors of plant defense responses from biocontrol strains of Trichoderma virens. Phytopathology 94:171-176.

6. Highley, T. L., Anantha Padmanabha, H. S., and Howell, C. R. 1997. Control of wood decay by Trichoderma (Gliocladium) virens. Mater. Organismen 31:157-166.

7. Howell, C. R. 1982. Effects of Gliocladium virens on Pythium ultimum, Rhizoctonia solani, and damping-off of cotton seedlings. Phytopathology 72:496-498.

8. Howell, C. R. 1987. Relevance of mycoparasitism in the biological control of Rhizoctonia solani by Gliocladium virens. Phytopathology 77:992-994.

9. Howell, C. R. 1991. Biological control of Pythium damping-off of cotton with seed-coating preparations of Gliocladium virens. Phytopathology 81:739-741.

10. Howell, C. R. 2002. Cotton seedling preemergence damping-off incited by Rhizopus oryzae and Pythium spp. and its biological control with Trichoderma spp. Phytopathology 92:177-180.

11. Howell, C. R. 2003. Mechanisms employed by Trichoderma species in the biological control of plant diseases: The history and evolution of current concepts. Plant Dis. 87:4-10.

12. Howell, C. R. 2004. Cotton seedling disease control with biological/ chemical seed treatments. Proc. Beltwide Cotton Conf. Page 421. National Cotton Council, Memphis, TN.

13. Howell, C. R., DeVay, J. E., Garber, R. H., and Batson, W. E. 1997. Field control of cotton seedling diseases with Trichoderma virens in combination with fungicide seed treatments. J. Cotton Sci. 1:15-20.

14. Howell, C. R., Hanson, L. E., Stipanovic, R. D., Puckhaber, L. S., and Wheeler, M. H. 2000. Induction of terpenoid synthesis in cotton roots and control of Rhizoctonia solani by seed treatment with Trichoderma virens. Phytopathology 90:248-252.

15. Howell, C. R., and Puckhaber, L. S. 2005. A study of the characteristics of "P" and "Q" strains of Trichoderma virens to account for differences in biological control efficacy against cotton seedling diseases. Biol. Control 33:217-222.

16. Howell, C. R., and Stipanovic, R. D. 1983. Gliovirin, a new antibiotic from Gliocladium virens and its role in the biological control of Pythium ultimum. Can. J. Microbiol. 29:321-324.

17. Howell, C. R., and Stipanovic, R. D. 1984. Phytotoxicity to crop plants and herbicidal effects on weeds of viridiol produced by Gliocladium virens. Phytopathology 74:1346-1349.
18. Howell, C. R., and Stipanovic, R. D. 1995. Mechanisms in the biocontrol of Rhizoctonia solani-induced cotton seedling disease by Gliocladium virens: Antibiosis. Phytopathology 85:469-472.

19. Howell, C. R., Stipanovic, R. D., and Lumsden, R. D. 1993. Antibiotic production by strains of Gliocladium virens and its relation to the biocontrol of cotton seedling diseases. Biocontrol Sci. Technol. 3:435440 .

20. Lumsden, R. D., Locke, J. C., Adkins, S. T., Walter, J. F., and Ridout, C. J. 1992. Isolation and localization of the antibiotic gliotoxin produced by Gliocladium virens from alginate prill in soil and soilless media. Phytopathology 82:230-235.

21. Thomson, W. T. 1997. Page 102 in: Agricultural Chemicals, Book IVFungicides. W. T. Thomson ed. Thomson Publications, Fresno, CA

22. Tu, J. C. 1980. Gliocladium virens, a destructive mycoparasite of Sclerotinia sclerotiorum. Phytopathology 70:670-674.

23. Weindling, R. 1932. Trichoderma lignorum as a parasite of other soil fungi. Phytopathology 32:837-845.

24. Weindling, R. 1941. Experimental consideration of the mold toxins of Gliocladium and Trichoderma. Phytopathology 31:991-1003.

25. Weist, A., Grzegorski, D., Xu, B. W., Goulard, C., Rebuffat, S., Ebbole, D. J., Bodo, B., and Kenerley, C. M. 2002. Identification of peptaibols from Trichoderma virens and cloning of a peptaibol synthetase. J. Biol. Chem. 23:20862-20868.

26. Wilhite, S. E., Lumsden, R. D., and Straney, D. C. 1994. Mutational analysis of gliotoxin production by the biocontrol fungus Gliocladium virens in relation to suppression of Pythium damping-off. Phytopathology 84:816-821.

27. Yedidia, I., Benhamou, N., and Chet, I. 1999. Induction of defense responses in cucumber plants (Cucumeris sativus L.) by the biocontrol agent Trichoderma harzianum. Appl. Environ. Microbiol. 65:1061-1070.

28. Zhang, J. 1995. Identification and pathogenicity of Fusarium species associated with cotton seedling roots, and their interactions with biocontrol agents and other soil-borne pathogens. Ph.D. diss. Texas A\&M University, College Station, TX.

29. Zhang, J., Bruton, B. D., Howell, C. R., and Miller, M. E. 1999. Potential of Trichoderma virens for biocontrol of root rot and vine decline in Cucumis melo L. caused by Monosporascus cannonballus. Subtrop. Plant Sci. 51:29-37.

30. Zhang, J., Howell, C. R., and Starr, J. L. 1996. Suppression of Fusarium colonization of cotton roots and Fusarium wilt by seed treatments with Gliocladium virens and Bacillus subtilis. Biocontrol Sci. Technol. 6: 175-187. 